Bagi Gábor

\title{
A szolnoki vár egykori alagútjai nyomában - Adalékok egy elfeledett régészeti ásatás történetéhez a szolnoki várban 1934/35-ben
}

Bagi, Gábor: Tracking the Tunnels of Szolnok Castle (Data to the history of a forgotten excavation)

There was a recurring news in Szolnok that beneath the castle tunnels could be found. Finally the Artists' Colony of Szolnok (the Pólya brothers, Ferenc Chiovini, Lajos Jancsó director) initiated an excavation in 1934 to clarify the situation. It was reported at the end of May 1935 when the excavation closed that remains of a 600-700 year-old church was unearthed in the castle parish garden and the supposed entrance of the tunnel could be the crypt of that church. However the parish-priest made the work stop because the parsonage wall was attached to the church and he feared for damages. Presumably the documentation of the excavation was perished in 1944 with the documents of the Art Association.

The amateur excavation was not identified during the excavations in 1973 and today's archaeologists in Szolnok do not know the bygone events. However data comparison shows that the two excavations touched two different parts of the same archaeological object (the Ottoman mosque and the old gothic Christian church), so thus they belong together. When the local media talks about the possible restoration of Ottoman-Turkish buildings in Szolnok it is not needless to analyze that excavation because the remains can easily conceal the oldest building of Szolnok.

Keywords: Szolnok, castle, tunnels, church, mosque

\section{ÖsSZEFOGLALó}

Szolnokon az elmúlt évszázadokban gyakorta visszatérő hír volt, hogy a vár alatt középkori alagutak húzódnak. Végül 1934-ben a Szolnoki Művésztelep (a Pólya testvérek, Chiovini Ferenc, Jancsó Lajos igazgató) ásatást kezdeményezett a helyzet tisztázására. A munkák 1935. május végi lezárásakor jelezték, hogy a várplébánia kertjében 6-700 éves templom maradványaira bukkantak, és az alagút lejáratának vélt üreg a templom kriptája lehetett. A plébános azonban a munkákat leállíttatta, mivel a templom oldalfalára épült plébánia épületét féltette. Feltételezhetően az ásatás dokumentációja a Művészeti Egyesület anyagával együtt 1944-ben semmisült meg.
Az amatőr ásatás régészeti azonositásával az 1973-as feltárások során nem foglalkoztak, és napjaink szolnoki régészei már nem is tudnak az egykori eseményekről. Az adatokat összevetve azonban kitűnik, hogy a két feltárás egyazon régészeti objektum (a török kori dzsámi és a régi gótikus keresztény templom) két eltérő felét érintette, és így az egybe tartozik. Amikor a helyi média szolnoki oszmán-török épületek esetleges helyreállításáról beszél, nem felesleges az ásatás elemzése, mivel a maradványok könnyen Szolnok legrégibb ismert épületét rejthetik.

Kulcsszavak: Szolnok, vár, alagút, vártemplom, dzsámi 
Ha Szolnokon az idősebb generáció tagjaival beszélgetünk, a körükben még mostanság is gyakorta feltűnik az a szakemberek által már rég elvetett állítólagos emlékkép, miszerint fiatal korukban ők még a szolnoki vár régi alagútjaiban járkáltak, illetve hogy ekkoriban a szülők, nagyszülők ismeretségi körében még maguk is találkoztak olyan élő, idősebb személyekkel, akik magukról ilyesmit állítottak. Sőt nem csak az idősebb generáció körében.

E sorok írója három évvel ezelőtt a Magyar Nemzeti Levéltár Jász-Nagykun-Szolnok Megyei Levéltárában maga is találkozott olyan - nála fiatalabb - helytörténeti kutatóval, aki ugyanezt a történetet mondta el. De nem csak ezt ... A mondai „emlékek” immár sokadik változatának tekinthető az a hiedelem, miszerint a római császárok által üldözött őskeresztények által készített Tisza alatti alagút máig is létezik, és arra időről-időre sokan rábukkannak a szolnoki lakosok közül.

A régész és történész szakemberek számára teljesen abszurd minden ilyen elképzelés. Egy alföldi, Tisza menti város esetében egyszerűen lehetetlen, hogy az itteni, nem köves talajban egyáltalán ilyen munkákba belekezdjenek. Ehhez még ma is hiányoztak a megfelelő mérnöki ismeretek, de a régmúlt évszázadokban sem lehetett ehhez elegendő számú szakképzett munkaerőt, valamint megfelelő minőségű és mennyiségü építőanyagot egybegyüjteni. Egy ilyen építészeti alkotás sikeres elkészítése mellett az is teljességgel elképzelhetetlen, hogy az itteni viszonyok között az több száz, vagy akár másfélezer esztendőn át tartósan megmaradjon. A Tisza és a Zagyva alatti alagutakkal kapcsolatos különböző történetek tehát így a mesék világába sorolhatók lennének. Nemritkán azonban mégis kiderül, hogy az ilyen hiedelmeknek olykor van valamiféle konkrét valóságalapja. Ez pedig lehet egy más jellegű régi építmény, pl. pince, vagy éppen felrobbantott második világháborús erődítésrészlet, ami aztán váratlan előkerülése után az átlagemberek által időben és korban teljesen félredatáltan, egy új, bár abszolút történetietlen összefüggésben jelenik meg.

\section{A SZOLNOKI VÁR TUDOMÁNYOS KUTATÁSÁNAK KEZDETEI}

Mint általában mindenhol, így hazánkban is a történeti kutatások kezdetei jóval megelőzték a tudományosan megalapozott régészeti ásatásokat. Szolnok várainak története ${ }^{1}$ már a XVIII. század végétől kezdve izgatta a helyi lakosokat, és 1821/22-ben Gorove László (1780-1839)², Szolnok első helytörténésze, az akadémiai tudományosság első helyi alakja már összefoglalta az ezekkel kapcsolatos ismereteket [GOROVE 1820: 3-32.; 1820a: 35-57.; 1820b: 65-87.; 1821: 38-62.; 1821a: 45-82.]. Gorove munkásságát időben - több mint fél évszázad elteltével - Somogyi Ignácé (1859-1889)³ követte, aki jórészt elveszett kéziratos munkája mellett több hírlapi cikkben is foglalkozott a helyi erödítések történetével [SOMOGYI 1885:, 1886:, 1887:, é.n.].

Somogyi után közvetlenül Illéssy János (1861-1905), [Bagi 2005:339-360] a Magyar Országos Levéltár főlevéltárosa [ILLÉSSY 1893: 635-666.] és Szendrei János (1857-1927) történész [SZENDREI 1889: 125-140.] tevékenysége említhető, akik azonban már nem helyi, hanem országos történeti szempontból írtak a szolnoki várak históriájának egyes szakaszairól.

Illéssyvel és Szendreivel csaknem egyidejűleg a szolnoki múzeumi gyújteményalapító és programadó Hild Viktor (1855-1929) [Bagi 1998:22-26] is foglalkozott Szolnok erődítményeinek történetével. Hild minden tudományos

${ }^{1}$ Szolnokon legkevesebb öt vár létezésével kell számolnunk az elmúlt egy évezred során. Ezek az alábbiak: 1. az Árpádkori ispánsági vár (a XI. századtól 1241-ig), 2. a magyarok által épített, majd a török és a Habsburg csapatok által is többször felújított végvár (1550-től 1704-ig), 3. az első kuruc vár (1704 nyarától 1706. szeptember 4-ig), 4. a Rabutin tábornagy által épített császári erőd (1706. szeptember 4-től 1707. január közepéig), 5. a második kuruc vár és annak átépítései (1710. ápr. 20-tól 1876-ig).

${ }^{2}$ Munkásságára lásd BAGI 2011: 46-56.

${ }^{3}$ BAGI é.n. Somogyi publikációs listája kapcsán köszönettel tartozom Kósa Károly könyvtáros-helytörténész barátomnak önzetlen segítségéért. 
eredménye ellenére is sokkal inkább adatgyüjtő, és nem összegző, feldolgozó kutató volt. Ezt jól mutatja a témával kapcsolatban 1894-ben megjelent - egyébként egyetlen történeti tanulmánya is, amely már megjelenése idején komoly szakmai hiányosságokkal rendelkezett. Ennek ellenére Hild azt harminc esztendő elteltével, 1926-ban ezt a dolgozatot változatlan formában mégis újra kiadta [HILD 1894, 1926.] Bármennyire is furcsa azonban, Hild ezen, éppenséggel nem korszakalkotó munkája kapcsán mégis elképzelhető, hogy az - ha akaratlanul is - elindítója lett az 1930-as években a szolnoki vár első átfogó, bár igen sajátos régészeti kutatásának.

Ebben a látszólag váratlan fejleményben a hazai régészet közel évszázados fejlődésének sajátosságai is komolyan közrejátszottak. A magyar archeológia a dualista korban vált nagykorú tudománnyá. 1858-ban alakult meg a Magyar Tudományos Akadémia Régészeti Bizottmánya, mely 1859-től folyóiratot adott ki „Archeológiai Közlemények” néven. Rómer Flóris (1815-1889), a magyar régészet atyja 1863-tól már mürégészetet tanított a pesti egyetemen, majd a javaslatára 1869-től rendszeresen kiadták az „Archaeológiai Értesítö”-t. Az első tervezett kutatások az 1860-as évektől indultak meg, és a századfordulóig gombamód megszaporodtak a vidéki régészeti társulatok (pl. a Tiszazugban és Tiszafüreden) és a múzeumok is. Előbb a már meglévő leletek feldolgozása folyt, de idővel a tervszerű ásatások is megsokasodtak. Bár Trianon a pénzszúke miatt a régészeti kutatásokat visszavetette, mégis egy tervszerübb, racionálisabb, az ásatások és feldolgozások egyensúlyát hozó korszakot indított el. Elkészültek a főbb régészeti korok első átfogó hazai feldolgozásai, ami lehetővé tette az egyéni eredmények jobb beillesztését a magyar tudományos köztudatba. [VÉKONY 2003: 16-20] Ezek voltak azok az eredmények és tényezők, amelyek az egykori szolnoki vár terüle- tének egy részén alakult Szolnoki Művésztelep művészeit cselekvésre ösztönözték, miután a figyelmüket a helyi szóbeszéd egy érdekes régészeti probléma felé irányította.

\section{Az 1934/35-ös ÁSATÁs MEGINDÍTÁSÁRóL}

1934 őszén a Szolnoki Művésztelep művészei Pólya Tibor (1886-1937), a testvére Iván (1889-1939) és Chiovini Ferenc (1899-1981), valamint Jancsó Lajos, a telep igazgatója vezetésével ásatásokat kezdeményeztek az egykori Vár területén, hogy az egyre sokasodó hírek igazságát felderítsék. Maga a munka utóbb szinte teljesen kikopott a város történetének kollektív emlékezetéből, mindazonáltal „amatőr jellege” ellenére sem szabad teljesen megfeledkezni róla. Egyrészt azért nem, mert 1950-ig a hazai ásatások többsége ilyen jellegű volt, másrészt pedig mivel a munkálatok előtt már számos helyi „mondai” adalékot gyüjtöttek össze a helyi művészek a lehetőségek pontos tisztázására. A „Szolnoki Újság” 1934. szeptember 27-i száma ${ }^{4}$ nemcsak azért érdekes, mert a munkálatok elkezdéséről tudósít, hanem mert az alig ellenőrizhető előzmények kapcsán is számos igen érdekes - bár sok esetben még további pontosítást és vizsgálatokat igénylő - , adalékkal szolgált. Egyúttal természetesen még több téves, hamis elképzelés is megfigyelhető a leírásokban, ám a napjainkra felgyűlt ismeretek alapján már elég jól elkülöníthetők a konkrétumok és a lakosság körében élt különféle hiedelmek.

„A történelem, a tankönyvek, a hagyomány egyaránt megállapítja, hogy Szolnok úgyszólván a magyarok itteni történelmi ideje óta megerősített hely volt - sőt félelmetesen erős földvár - amelynek fontosságát mi sem jellemezte job-

${ }^{4}$ Külön köszönettel tartozom Bojtos Gábor levéltáros barátomnak (Magyar Nemzeti Levéltár, Jász-Nagykun-Szolnok Megyei Levéltára), aki a cikkre felhívta a figyelmemet, sőt azt másolatban a rendelkezésemre bocsátotta. 
ban, - minthogy állandóan ádáz harcok dúltak birtokáért. Egészen természetes, hogy egy ilyen megerősített hely védelmi műveiben a régi időkben jelentős szerepet játszottak a föld alatti kazamaták, - titkos folyosók stb., amelyek más erejű műemlékek, $-\mathrm{s}$ az is egészen bizonyos, hogy a szolnoki vár is hasonló berendezkedésű volt, - s csodálatos ! - még sincs semmiféle emlék, vagy csak biztos leírás sem, a szolnoki vár földalatti részéről. Pedig Szolnokon még csak a vár helyét sem kell kutatni, mint legtöbb esetben másutt, - mert bizony az ott volt, ahol ma, a „Vár" nevű városrész elterül.

A szolnoki Múvésztelepnek jutott az a feladat, hogy Szolnoknak ezeket a régi emlékeit

Az első impulzust az adta, hogy a mai Damjanich szobor ${ }^{5}$ mögött beomlott a föld. Rájöttek, hogy egy rég betemetett kút volt ott, amely egy üregbe torkollott. Jancsó Lajos, Pólya Tibor és Chiovini Ferenc lelkes örömmel fogtak az üreg feltárásához, - azt hivén, hogy a vár alagútját találták meg, - azonban hamarosan rájöttek, hogy hamis nyomon járnak. A kút ugyan elég értékes emlékanyagot adott, mert a falai gótikus stílusú kövekből épültek, - ami azt bizonyítja, hogy egy kb. 1200-1400 év körül épülhetett ház maradványait használták fel erre a célra, $s$ így eklatáns igazolása annak, hogy Szolnokon 7-800 évvel ezelőtt már fejlett stílusú épületeket emeltek.

A félsiker nem csüggesztette el a kutatókat s most már teljes energiával a szolnoki részének feltárására összpontosították energiájukat, - s amint halljuk - a legjobb úton haladnak - s a teljes siker, úgyszólván - órák kérdése.

Mielőtt azonban feltárulna a régi szolnoki földalatti vár, mi is jónak tartottuk utána nézni, hogy mi is az igazság az alagút ügyében.

5 Radnai Béla ma is meglévő alkotásáról van szó, a Művésztelep mellett, a Zagyva közelében. városokban és várakban manapság nagy vonzófeltárja.

Elsősorban is azt kell megállapítanunk, - anélkül azonban, hogy a festőművészeink ambíciózus munkájának értékét legkevésbé is csökkenteni akarnók, - hogy az ötlet nem új, mert már régebben is kutatták a vár alagútjait, sőt részben eredményeket is értek el.

A legutolsó szolnoki várat 1550 körül Dobó István építette kerek 4 esztendőn át. ${ }^{6}$ A török 1552ben elfoglalta s még tovább fejlesztette védelmi műveit. Egykorú feljegyzések szerint a vár alatt terméskő boltozatú folyosó hálózat vonult végig, amely oly széles volt, hogy két kocsi elfért benne egymás mellett. A folyosó a vízre torkollott éspedig két vízikapun át, amelyek közül az egyik a Tiszára, a másik a Zagyvára nyílott.

A tiszti kapu ${ }^{7}$ minden kétséget kizárólag a Sáry biró háza ${ }^{8}$ és a vár kerítésének találkozásánál volt. Itt ugyanis 1922-ben beszakadt a föld és Kiss Ferenc városi üzemi altiszt le is szállott a kb. 6-7 méter mélyen fekvő kazamatába s 3040 méter hosszúságnyira járt is benne. Ezt a nyilást azóta betömték.

Hasonlóan nyilatkozik Kozma János 74 éves ácsmester is, aki 30 évvel ezelőtt Sáry bíró házjavitásánál segédkezett, és a pince alatt szintén felfedezett egy bolthajtásos folyosót. Kozma leszállott az üregbe, de 10 lépés után vissza is fordult, mert igen rossz volt bent a levegő.

A várbeli szájhagyományok szerint 50 évvel ezelőtt egy Kovács István nevű utcaseprő is ráakadt a folyosóra, sőt be is járta az egészet.

\footnotetext{
Természetesen ez az újságcikk is - mint a legtöbb! igen komoly tárgyi tévedéseket, sőt matematikai abszurditásokat tartalmazott. Dobó István egri főkapitány csak a munkálatok elindításában játszott fontos, bár nem egyedüli szerepet. Az építkezés ugyan feltehetően még 1552-ben is folyt, ám ez év szeptember 4-én a török bevette a várat. Így Szolnokon az építkezések megkezdése és az erőd eleste között valamivel kevesebb mint két év telt el, semmi esetre sem négy!

${ }^{7}$ Talán a tiszai vagy vízi kapuról van szó.

8 Pillanatnyilag nem azonosítható hely. 1906-ban Sáry törvényszéki bíró háza (38. számmal!) a Tabánban volt, tehát a Zagyva túloldalán. Így ez nem jöhet számításba.
}

ECONOMICA 2013/2 
Kovács vadonat új kabátját letette, hogy össze ne piszkolódjék az üregben, de a tekervényes labirintusban eltévedt és többé nem találta meg a kabátját. Rémülten került a felszínre, $s$ többé nem is ment a kabátja után, amelyet bizonyára a vár szellemei tulajdonítottak el a betolakodóktól.

Kutatott még az alagút után Virág János adóhivatali igazgató is, azonban ő sem tudott a titokra teljes fényt deríteni.

Az majdnem bizonyosra vehető, hogy a második, - a Zagyvára néző - a Művésztelep házmester lakása ${ }^{9}$ mögött torkollott a folyóra $\mathrm{s}$ így most ezen részen kisérlik meg a folyosó feltárását.

A mennyiben tényleg siker koronázza az ambíciózus kutatók fáradozását, - Szolnok egy igen értékes műemlékkel gyarapodik, amelyet időtálló állapotba lehet hozni, - villanyt bevezetni az érdeklődők számára - s végül az sem lehetetlen, hogy nagy jelentőségű történeti dokumentumokat is tartalmaz a titkos alagút. A lejáratot természetesen a Múvésztelep kertjében kellene kiépíteni s egy pár fillért is be lehetne szedni a látogatóktól, amiből megtérülne az alagút fenntartási és gondozási költsége.

Nem volna azonban teljes a riportunk, ha azt a kedves esetet nem említenők, ami szintén szájhagyományként él a várbeliek között.

Volt 30-40 évvel ezelőtt Szolnokon egy Kállay nevű végrehajtó, igen tréfás ember, aki állitólag szintén megtalálta az alagút bejáratát és lejárt abba. Benn az alagútban Kállay döngette a falakat, harangozott stb. - egyszóval nagyzajt csinált, - miközben a földszínén a várbeli lakosok hányták magukra a keresztet s átkozták a pogányokat, hogy még holtuk után sem nyugodhatnak szellemeik s háborítják az élők nyugalmát.

Lehet, hogy nem igaz ez a történet, de igen kedves és hozzá tartozik a vár tradícójához, amelyet nem ártana már végre szakavatott kéz-

${ }_{9}^{9}$ Pillanatnyilag nem azonosítható objektum. zel össze gyűjteni, s úgy megörökíteni az utókor számára."

Két nappal az újságcikk megjelenése után a Magyar Távirati Iroda is rövid hírben adta tudtul a munkálatok megkezdését. A számos országos és vidéki lap által átvett rövid híradás az alábbiakat tartalmazta:

„Szolnok. Szeptember 29. Pólya Tibor, Pólya Iván és Chiovini Ferenc, a szolnoki művésztelep festőmúvészei és Jancsó Lajos, a telep igazgatója, egy beomlott kút nyomán nagyszabású ásatásokat kezdtek a régi szolnoki vár földalatti folyosóinak felkutatására. Régi feljegyzések szerint a szolnoki vár egész területe alatt öt-hat méter mélyen valóságos folyosó útvesztő vezetett, amely terméskővel volt boltozva, s olyan széles volt, hogy két kocsi elfért benne egymás mellett."10

Sajnos magukról az ásatási munkálatokról a helyi újságok nem közöltek semmit. Nem ismert, hogy pontosan mikor és hol kezdték a munkát, hány emberrel dolgoztak, valamint hogy mikor tartottak a téli időjárás miatt szünetet és milyen hosszú ideig.

\section{AZ 1934/35-ÖS ÁSATÁSOK EREDMÉNYEIRŐL}

Nagy valószínűség szerint az elkezdett ásatások a téli szünet után 1935 tavaszán folytatódtak. Hogy a művészek a munka ekkori időtartama mely területeket vizsgálták át, az pillanatnyilag ugyancsak nem ismeretes. Sajnos régész végzettségü személy tudtunkkal nem volt jelen a munkálatok során, így számolhatunk esetleges hibákkal is. A munkálatok végül május utolsó hetében hoztak váratlan sikert, és még e hónap végén, vagy június legelején zárultak le. Ezt bizonyítja, hogy a Magyar Távirati Iroda június 4-én az események kapcsán alábbi tudósítást tette közzé:

${ }_{10}$ Magyar Távirati Iroda, 1934. szeptember 29. 13. óra 15. perc. Internet: http://mol.arcanum.hu/mti/opt/ a 100929. htm ? v=pdf\&q=WRD\%3D\%28Szolnoki\%20 v\%E1r\%29\&s=SORT\&m=0\&a=rec 
„Szolnok, június 4. A szolnoki művészeti egyesület már hosszabb ideje ásatásokat folytat a régi szolnoki vár területén, hogy megtalálják a hagyomány szerinti vár alatt elhúzódó titkos alagutat. Az alagút lejárata a szemtanuk állitása szerint a várplébánia kertjében volt. Ásatás közben a várplébánia kertjében egy 6-700 éves régi templom alapjaira bukkantak, amelynek oldalfalai és a torony alapzata - egészen napvilágra került. A múvészeti egyesület megállapítása szerint a szolnoki vártemplomot valószínűleg ennek a templomnak a köveiből építették fel annakidején. Ezzel egyidejűleg világosság vetődött az alagút lejáratának kérdésére is, mert valószínűnek látszik, hogy a szemtanuk által az alagút lejáratának vélt üreg a templom kriptája volt." ${ }^{\prime 1}$

A rövid tudósítás bizonnyal alaposan felcsigázhatta a helybeliek érdeklődését, mivel a „Szolnoki Újság” június 6-i számában ${ }^{12}$ egy valamivel hosszabb tudósítás jelent meg az ásatás körülményeiről, valamint annak eredményeiről.

„Régebben volt már szó róla, hogy a szolnoki vár alatt valahol lennie kell egy alagútnak, amely a várőrség észrevétlen eltávozását volt hivatva szolgálni és több szavahihető tanú állította, hogy még 15-20 évvel ezelőtt is járt lent az alagút bejáratában.

A szolnoki művésztelep igazgatósága erősen ambicionálta az alagút megtalálását, amelynek sikerülte esetén Szolnok páratlan értékű múemlékkel s egyben nagy idegenforgalmi vonzóerővel is gyarapodnék, azonban ezideig, különösen a várplébánia ellenállása miatt nem tudott eredményt elérni az ásatás.

Amint értesültünk, a mult hét folyamán a várplébánia kertjében végzett ásatások nagyszerü

\footnotetext{
${ }^{11}$ Magyar Távirati Iroda, 1935. június 4. 20 óra 45 perc. Internet: http://mol.arcanum.hu/mti/opt/a100929.htm?v =pdf\&q=WRD\%3D\%28Szolnoki\%20v\%E1r\%29\&s=SORT $\& m=2 \& a=r e c$

${ }^{12}$ Idézi még KÓSA 2000, 157.
}

felfedezést eredményeztek, mert sikerült megtalálni egy kb. 6-700 éves templomalapjait.

A templom oldalfalára épült a mai plébánia épület és az ásatások már feltárták a templom tornyának és a mellette elhúzódó falnak részleteit. A templom valószínúleg az a bizonyos legrégibb szolnoki templom lehetett, amelyet a törökök mecsetté alakítottak át, s az idők folyamán ennek köveiből épült fel a mai vártemplom.

Ezzel a felfedezéssel némi világosság is derült a titokzatos alatti alagút problémájára is, -- mivel a tanúk vallomása mind e helyre teszi a lejáratát annak, -- s így valószínű, hogy nem alagútról van itt szó, hanem csupán a régi templom alatti kripta ürgekről.

A müvésztelep most ezen pozitiv eredmények után nagy ambicióval folytatná az ásatásokat tovább, azonban, amint halljuk, most már az egyházközség vezetősége támaszt akadályokat s állítólag a további ásatások beszüntetését szorgalmazza. Remélhetőleg az egyházközség revideálja álláspontját és az ásatások tovább folytatódnak a történeti emlékek felkutatása érdekében."

Még ugyanezen a napon, június 6-án a fő vármegyei újság, a „Jász-Nagykun-Szolnok Megyei Lapok" is beszámolt egy rövid hírben az eseményekről. Ez a következőket tartalmazta:

„Középkori templom alapjaira bukkantak a plébánia kertjében a Szolnoki Művészeti Egyesület Chiovini Ferenc által vezetett ásatásai során. Hagyomány szerint az egykori vár alatt titkos alagút húzódik. Ezek a bejáratát régen kutatják, s ez ... azután tárták fel az ősi templom oldalt, s toronyfal-alapzatát. A történeti becsü maradványok további feltárása szünetel, mert a várplébános engedélye nélkül a plébánia kertben a munkálatokat nem lehet folytatni. Valószínű, hogy rövidesen több neves régész érkezik városunkba a középkori eredetű műemlék maradványok megtekintésére."

Ha elfogadjuk - s ebben nincs okunk kételkedni - , hogy a plébánia épülete valóban az 
egykori templom egyik oldalfalára épült, akkor eléggé nyilvánvaló, hogy a Vártemplom plébánosa miért nem engedélyezte a további munkálatokat. Nem a tudomány iránti ellenszenvről, vagy eredményeinek lebecsüléséről lehetett szó. Egyszerüen a plébánia épületét félthette, mivel az alapok bolygatása az épület stabilitását is komolyan veszélyeztethette.

Nagyon valószínű, hogy az ásatás kapcsán készülhettek a feltárt objektumokról helyszínrajzok, illetve valamiféle leírások, ma úgy is mondhatnánk ásatási jelentések. Sajnos azonban magunk a Szolnok városi, valamint a JászNagykun-Szolnok megyei levéltári anyagában ezeket nem találtuk meg. Még inkább feltűnő, hogy az ásatásokra történő hivatalos utalásokról sem tudunk, de még csak a munkák megindításával kapcsolatos hivatalos engedélyeztetési eljárásról sem került elő semmi. Lehetséges, sőt valószínű, hogy a Váci Püspökséghez, illetve a Nemzeti Múzeumhoz végül eljutott valamiféle tudósítás, az ügyhöz kapcsolódó részletes dokumentáció viszont bizonnyal a Szolnoki Múvészeti Egyesület anyagába kerülhetett be. Sajnos azonban ez a Múvésztelep több ezres képzőművészeti gyűjteményével és más irataival együtt 1944-ben nyomtalanul eltűnt, nagy valószínűség szerint teljesen megsemmisült.

\section{Mit IS TALÁLHATtAK 1935-Ben?}

Az elmondottak után joggal felvetődik a kérdés, hogy vajon az ásató müvészek vajon mit is találtak 1935-ben. Szolnok város történetével foglalkozó történészként egyszerűen döbbenetes felfedezni, hogy az egykori újságcikkekben jelzett ásatási helyszín (a várplébánia udvara) az ismert adatok szerint pontosan a mellett a terület mellett helyezkedik el, ahol Kaposvári Gyula múzeumigazgató és az egyetem után épp ide került Csányi Marietta régész 1973-ban a szolnoki török dzsámi maradványait megtalálta.

A dzsámi a mohamedánok számára istentisz- teleti hely, azaz imaház, ahol a pénteki szentbeszéd (hutbe) elmondható. Az elnevezés a 11. században, a Fatimida-kori Egyiptomban tűnt fel először, majd fokozatosan elterjedt az iszlám világban. Szolnokon az első keresztény templom és a török dzsámi kapcsolatát erősíti az a felismerés, hogy a török által elfoglalt városokban általában a főtemplom átalakítására került sor elsőnek, és ezeket a dzsámikat arról a szultánról nevezték el, aki uralkodása alatt került sor a hódításra. Az oszmánok így alakíthattak ki korai imahelyeket, ahol elmondhatták a város vagy vár elfoglalásáért a hálaadó istentiszteletet. Bár ez a törvényszerűség nem általánosítható minden esetre, a szolnoki keresztény templom és a török imahely kapcsolatát mégis valószínűvé teszi.

A szolnoki Damjanich János Múzeum szakemberei (Kaposvári Gyula, Csányi Marietta) 1973-ban már a plébánia kerítésén kívüli közterületen ástak, azaz részint már a feltételezett gótikus templom mellett. A közzétett ásatási jelentésük szerint a feltárt „szögletes alaprajzú dzsámi egyik oldala 15,9 m, az erre merőleges falakból csak 5,6 m-es szakaszt tártunk fel, mert a szomszéd telken lévő plébánia területére húzódik át. A dzsáminak csupán kiszedett alapárkát tártuk fel, mélysége 1,3-1,5 m, földvastagsága $1,5 \mathrm{~m} .{ }^{\prime 13}$

\footnotetext{
${ }^{13} \mathrm{~A}$ Budapestre felküldött, majd megjelentetett teljes ásatási jelentés a következőket tartalmazta:

„Szolnok-Vár, Gutenberg tér 4. /Szolnok m./ /XXXVIII./ A régészetileg védett területen - a 18. sz. kéziratos térképek felhasználásával -, a vizikapu közelében megtaláltuk a dzsámi falának alapárkait és a mellette lévő minaret alapozását.

A szögletes alaprajzú dzsámi egyik oldala 15,9 m, az erre merőleges falakból csak 5,6 m-es szakaszt tártunk fel, mert a szomszéd telken lévő plébánia területére húzódik át. $A$ dzsáminak csupán kiszedett alapárkát tártuk fel, mélysége 1,3-1,5 m.

A dzsámi Ny-i falához tapadóan találtuk meg a minaret négyzet alakú alapzatát; mérete 3,9 × 3,9 m. Az 1,5 m magas alapzatát; mérete $3,9 \times 3,9 \mathrm{~m}$. Az 1,5 m magas alapzat alsó részén egymás mellé helyezett gerendák nyomai
} 
Minthogy a két ásatás területileg kiegészíti egymást, joggal vetődik fel a kérdés, hogy 1973ban a Damjanich Múzeum régészei tudtak-e az 1934/35-ös eseményekről. Dr. Csányi Marietta régész osztályvezető kolleganőnk elmondása szerint erről maga egyértelmúen nem rendelkezett ismeretekkel, és a későbbiekben bronzkorosként nem is tarthatta magát illetékesnek a törökkor kapcsán. Kaposvári Gyula leánya, Kovácsné Dr. Kaposvári Gyöngyi közlése szerint a jelzett években édesapja már egyetemi tanulmányait megkezdve Budapesten lakott, és a másik családtag, Dr. Selmeczi László régész sem tud Chioviniék egykori kezdeményezéséről. Mivel az 1973-as ásatásról megjelent újságcikkek sem utalnak a közel négy évtizedes előzményekre, első pillanatra nemmel kellene válaszolnunk a feltett kérdésre.

A helyzet azonban szerintünk ennél bonyolultabb, és valószínúnek tartjuk, hogy Kaposvári Gyula múzeumigazgatónak lehettek bizonyos ismeretei a 30-as évek eredményeiről. A rokonsága révén bizonnyal egyetemi évei alatt is értesült a főbb otthoni hírekröl, a fő forrás azonban talán mégis az egykori ásatást vezetőszervező Chiovini Ferenc festőmúvész lehetett, akivel annak az 1980-as években bekövetkezett haláláig igen szoros, baráti kapcsolatban volt.

találhatók. Fölötte mészbe ágyazott faragott kövek, majd kőtörmelék rétegesen. Az 1821-es bontáskor ez azért maradhatott meg, mert szétbontani lehetetlen.

A területet a XIII. század elején temetőnek használták. A feltárt 10 sír között gyermeksírt is találtunk gyöngyös pártával; egy férfi sírját pedig a fej alá helyezett, nemezből készült, un. kunsüveggel.

A területen a felszínre kerül $1 \mathrm{db}$ öntöttvasból készült billogvas, amely I. Ferenc korabeli magyar címert ábrázol; a kamarai uradalomé lehetett.

A középkori réteg alatt a bolygatatlan talajba nagyméretű, többosztatú őskori gödör mélyedt, melynek kb. háromnegyed része feltárásra került; a belőle erőkerült edénytöredékek a kora vaskorra keltezik.

Az ásatáson részt vettek: Kozák Károly, Stanczik Ilona, valamint Raczky Pál egy. hallgató."

(KAPOSVÁRI - CSÁNYI 1973: 104-105.)
Chiovini halála után Kaposvári Gyula több cikkben is utalt Szolnok Mohács előtti Vártemploma és a török dzsámi kapcsolatára, és azt a XVIXVII. századtól egységes régészeti objektumnak tekintette. Az 1935-ös ásatásra és a Szolnoki Múvészeti Egyesület elpusztult anyagára - véleményünk szerint talán szakmai okokból (nem hivatásos régészként) - már nem akart, vagy nem mert hivatkozni. Azonban láthatóan nem hagyta nyugodni a kérdés, és a továbbiakban egy egészen sajátos forráscsoportból, Szolnok történeti ábrázolásaiból igyekezett bizonyítékokat szerezni. 1983-ban megjelent tanulmányában Joseph Riemel 1753-as térképe alapján 11$12 m$ hosszúságúra és $6 m$ szélességűre becsülte a dzsámihoz kapcsolódó gótikus templom méreteit. [KAPOSVÁRI 1983: 190.] 1990-ben is utalt erre, bár némiképp óvatosabb formában. [KAPOSVÁRI 1990: 238.]

Sajnos Kaposvári Gyula 1998-ban meghalt, ám ekkoriban úgy tűnt, hogy a templom kutatásában mégis fordulat következik be. 2000-ben ugyanis Kósa Károly könyvtáros-helytörténész a V. Szász József által szerkesztett Szolnok történetben leközölt egy a várossal kapcsolatos, gondosan válogatott hírlapi cikkgyűjteményt, amelyben egyebek mellett ott volt az egyik 1935. júniusi újságcikk is a templom felfedezéséről. [KÓSA 2000: 157.] Elmondható azonban az, hogy az írók ezúttal sem olvastak, az olvasók pedig most sem írtak, így aztán akiket ez a kérdés komolyan kellett volna hogy érdekeljen, nem szenteltek figyelmet ennek a fejezetnek.

Sajnálatos módon ez a közömbösség jellemezte az elmúlt évtizedben a szolnoki vár története felé forduló - magát kő és török korosként meghatározó - régész muzeológust, Kertész Róbertet is. Ő ugyan a közelmúltban megkísérelte a szolnoki vár kutatástörténetét összeállítani, ámde alapos megelőző kutatások és komoly előtanulmányok hiányában munkája régészeti és a történelmi szempontból is hiányosra és komolyabb tévedésektől sem mentesre sikeredett. 
Ellentmondásos módon e „gyermekbetegségek” ellenére is összegzésében ellentmondást nem türő határozottsággal és „bizonyossággal” jelentette ki, hogy a Vár területén a közelmúltig csak egy számottevő ásatás folyt, az 1973-as [KERTÉSZ 2012: 44-46.] Kaposvári Gyula feltételezése - a gótikus keresztény templom és török dzsámi által alkotott közös régészeti objektum kapcsán véleményét (pontosabban kétkedését) az alábbiakban összegezte:

„... Kaposvári neve fémjelzi azt a napjainkig érvényben lévő teóriát, hogy a Riemel térképén (1753) a dzsámi keleti falának közepénél látható, téglalap alakú, keleti részén a nyolcszög három oldalával záródó épület a vár gótikus templomának feleltethető meg. Úgy képzelte, hogy Szolnok 1552-es elfoglalása után az oszmánok nemcsak teljesen épségben hagyták, hanem valójában ezt bővítették ki a nyugati falához épített négy- zet alaprajzú dzsámival, valamint minarettel. Szerinte ezt bizonyítják a XVIII. századi hadmérnöki felmérések, melyeken a muszlim imaház, és az általa gótikus templomnak (Riemel alapján az utóbbi Kaposvári Gyula által kiszámolt méretei: 11-12 m hosszú és $6 m$ széles) vélt épület együtt szerepel. [KERTÉSZ et al. 2012: 114.]"

Magam az 1935-ös ásatásról elmondottak alapján Kaposvári Gyula feltételezését jóval többnek tartom egyszerū teóriánál, amit talán egy váratlan helyről előkerült dokumentum is megerősíthet. 2012-ben Jámbor Csaba könyvtáros és Benedek Csaba néprajzos kollégámmal hoztuk be a szolnoki Damjanich Múzeumba az akkoriban elhunyt kiváló szolnoki építész, Pár Nándor (1947-2011) hagyatékát, amelyet a családtagok ingyen ajánlottak fel a szolnoki múzeumnak. 2013 nyarán leltároztam be az anyagot, és eközben meglepve fedeztem fel egy

1. ábra: A szolnoki dzsámi és a templom vázlatrajza

$$
M=1: 200
$$

Szt. István tér

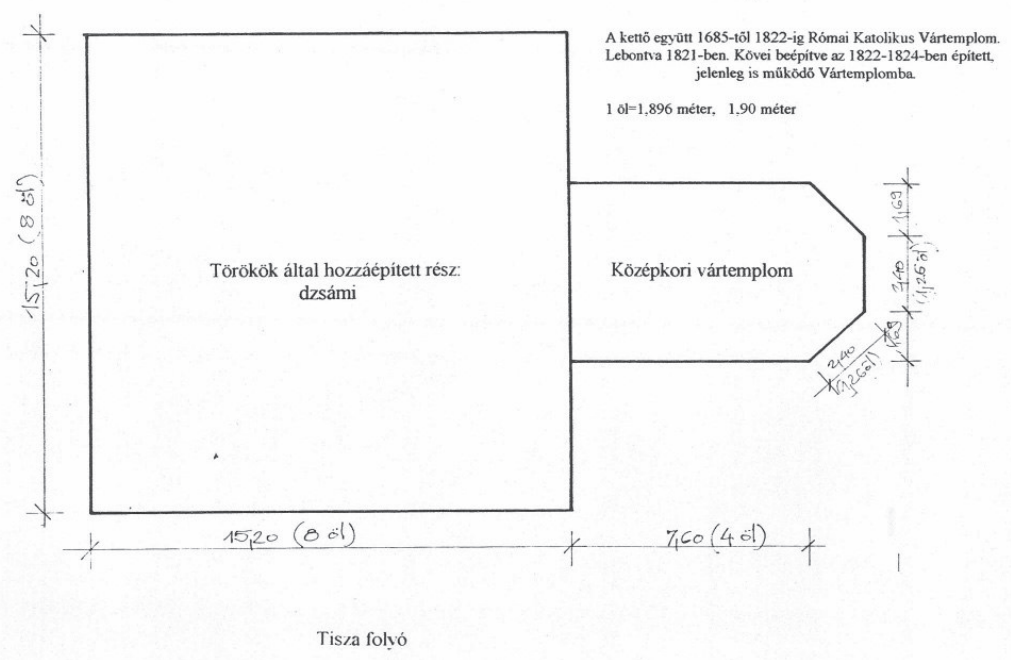

Forrás: Damjanich János Múzeum Helytörténeti Adattára 5296-03, Pár Nándor hagyaték 
tusrajzot, pontosabban annak egy fénymásolt változatát. Ez az 1 : 200 méretarányú vázlat a Kaposvári Gyula által feltételezett állapotában ábrázolja a szolnoki dzsámit és a templomot. A 8 x 8 öl (15,2 m x 15,2 m) nagyságú, négyzet alakú dzsámihoz kapcsolódó keresztény templomrész téglalap alakú volt, és a nyolcszög három oldalával záródott, azaz sok szempontból Riemel térképét véve alapul.

Némiképp elgondolkodtató azonban, hogy a rajz nem pontosan a Kaposvári Gyula által később megadott méretekkel ábrázolja a templomrészt. Ennek szélessége 3, míg a hosszúsága 5 öl (1 öl = 1,89 m), amiből egy öl esik a szentély több szögű záródására. Ez a hármas törésű falrész háromszor 2,4 m nagyságú volt. Sajnos a rajz készítésének körülményeiről nincsenek információink, de a jelek szerint Pár Nándor munkája lehet, és 1990 után készült. Ám hogy a készítő a munkához szükséges adatokat mikor és kitől nyerte, Kaposvári Gyulától, Chiovini Ferenctől, vagy esetleg más személyektől, az sajnos pillanatnyilag nem dönthető el.

\section{5. ÖSSZEGZÉS HELYETT}

E sorok írója a közelmúltban történészként szembesült az 1934/35-ös ásatások tényével, illetve az ezzel kapcsolatban leírtakkal. Noha ez az ásatás alig két évtized alatt kitörlődött a szolnokiak emlékezetéből, eredményei a munka „amatőr" jellege ellenére is elgondolkodtatóak. Véleményünk szerint mindenképp vitathatatlannak tekinthető, hogy az ekkori és az 1973-as ásatás helyszínei egymás mellett voltak, kiegészítették egymást. Amíg elsőnek egy régészeti objektum Várplébánia kertjébe eső részét tárták fel, addig másodszorra a plébánia kerítésén kívüli felére került sor. Az első ásatás dokumentációjának eltűnése miatt azonban a két feltárás eredményeinek nyilvános, hivatalos összekapcsolására nem került sor, bár a feladattal a jelek szerint Kaposvári Gyula múzeumigazgató komolyan foglalkozott.
Részint emiatt is mielőbb szükséges lenne az 1935-ös ásatás közölt eredményeinek ellenőrzésére, illetve pontosítása. Bár több szempontból is valószínűnek tűnik, de mégsem lezárt kérdés, hogy 1935-ben valóban az első, akkor 6-700 éves szolnoki templom maradványai kerültek-e elö, és hogy ezeket pontosan hol helyezkedtek, illetve helyezkednek el. Az újságcikkek egyértelműen a plébánia kertjében folyt ásatásokról szóltak, nagy kérdés azonban, hogy ez a terület teljesen egyezőnek tekinthető-e a maival. Még inkább elgondolkodtató az a közlés, miszerint a „templom oldalfalára épült a mai plébánia épület".

Ha azonban 1935-ben a Várplébánia kertjében valóban az első ismert szolnoki templom romjai kerültek elő, az nemcsak számos régészeti, hanem több várospolitikai, illetve szociáletikai kérdést is fölvet. Napjainkban ugyanis Szolnok kapcsán a helyi sőt az országos média egyes fórumai is alapvetően a török dzsámi virtuális, vagy részben valóságos újrateremtéséről beszélnek, különböző, sokszor megfelelően át nem gondolt tényekre és felelőtlenül nyilatkozó személyek által hibásan értelmezett történeti folyamatokra hivatkozva. ${ }^{14}$ Magam történészként úgy vélem, ha itt valóban az első szolnoki

\footnotetext{
${ }^{14}$ Sajnos e tekintetben a Damjanich Múzeum egyes szakemberei sem mutatnak túl jó példát: „Kertész Róbert - vázolva a dzsámihoz köthető történelmi hátteret - kiemelte: az oszmán uralommal a 16. században egy virágzó korszak kezdődött Szolnok életében (sic !!! - B. G.), ugyanis a törökök kereskedelmi és logisztikai központtá fejlesztették a várost. Az 1550-es években épült, és az akkori uralkodó, Szulejmán szultán nevét viselő dzsámi is ezt a feltevést igazolja." http://mizuscafe.hu/felterkepeztek-szulejmanszolnoki-dzsamijanak-pontos-helyet

Az oszmán uralom itteni kiépítését, a városnak és a várnak a muszlim világhatalom végvidéki határvédelmi rendszerébe való beillesztését, valamint a török hódítások utáni részleges újjáépítést még egy régésznek sem illene összetéveszten a virágzás, az általános fellendülés fogalmával. Különösen mivel minden török által meghódított, erődítménnyel rendelkező magyar város esetében megfigyelhető a mohamedán lakosság megjelenése, majd túlsúlyba kerülése a lakóhelyét elhagyó magyarsággal szemben.
} 
templom maradványai kerültek elő, úgy annak azonosítása, esetleges bemutatása, láthatóvá és látogathatóvá tétele sokkalta inkább erősíthetné a „szolnokiság” manapság annyira hiányolt eszméjét a helyi lakosságában, mint egy, a magyar nemzet történetében egyértelműen negativ és jóvátehetetlen következményekkel járó idegen (oszmán) hódítás emlékének indokolatlan kiemelése, vagy éppen nemzetidegen újrateremtése. Már csak azért is, mert egy ilyen lépés után komolyan fel kellene vetni a szovjet hősi emlékművek visszaállítását, a felszabadító román katona szobrának felállítását (amelyre csaknem sor került Szolnokon az 1960-as években) ${ }^{15}$, de akár még Batu kán Muhi pusztai lovasszobráról is vitát lehetne indítani.
Ebben a helyzetben elsőnek Anthony D. Smith szavait tudom megismételni. Eszerint a mesterséges hagyományalkotásnak lehet ugyan létjogosultsága, ám „a "kitalálást" mindenkor a meglévő elemek újfajta rekombinációjaként kell elérni. ${ }^{16}$ Még inkább megfontolásra érdemesek azonban Lővei Pálnak a nemzeti emlékhelyek kialakításáról írott szavai: „Emlékezni - akár emlékhelyen is - lehet jó dolog: felemelö, hosszú ideig emlékezetes. Ez azonban jól csak akkor szokott sikerülni, ha hagyománya valóban hagyomány: hosszabb időszaknak a spontaneitást sem nélkülöző eredménye. Nemzeti emlékhelyet nem szabad egyik percről a másikra a semmiből létrehozni - azt lenne szabad annak nyilvánítani, ami a nemzetben az azzá nyilvánítás nélkül is akként él." [GYÁNI 2010: 101.]
15 Dr. Szabó László, a közelben elhunyt kiváló néprajzos
kollégám elbeszélése szerint a malőrt Kaposvári Gyula
múzeumigazgató akadályozta meg, aki figyelmeztette az
MSZMP megyei és városi illetékeseit, hogy 1944 október
végén Szolnoknál egy román hadosztály azzal tagadta meg
a szovjetek előrenyomulási parancsát, hogy számukra vé-
get ért a háború, mivel elérték Nagy-Románia határát. A
hadosztályt végül a szovjet és a német tüzérség közösen
semmisítette meg. Arról egyébként az 1980-as években
a nemzetközis sajtó is írt, hogy az NKVD (a hírhedt KGB
elődje) Szolnok alatt több román alakulatot is megtizedelt.
16 Napjainkban a jászok és kunok kapcsán sokan sikeres mesterséges hagyományteremtésről beszélnek, ami a közösségszervezésnek is igen fontos eszköze. Ugyanakkor vannak ellenvélemények is, főleg különböző internetes oldalakon. PI. többen az ilyen törekvést „az egy före jutó hülyeségek" számának növeléseként értékelik. (Internet: http://www.nyest.hu/renhirek/kunok-legyunk-vagymagyarok?comments ) 
Felhasznált irodalom:

[1.] Bagi Gábor [1998]: Hild Viktor a történész-levéltáros. In.: Hild Viktor (1855-1929.) Egy tudós portréja. Szolnok, 22-26.

[2.] Bagi Gábor [2005]: Száz éve halt meg Illéssy János (1861-1905) történész-levéltáros. In.: Zounuk. A Jász-Nagykun-Szolnok Megyei Levéltár Évkönyve, 20. Szolnok, 339-360.

[3.] Bagi Gábor [2011]: Az akadémiai tudományosság első Jász-Nagykun-Szolnok megyei alakja: — adalékok gattájai Gorove László (1780-1839) életéhez és munkásságához. Jászkunság, 2011. 1-4. sz. 4656.

[4.] Bagi Gábor [é.n.]: Somogyi Ignác (1859-1889), Szolnok dualista kori monográfusa. Kézirat. (Megjelenik a Somogyi által írott Szolnok város történetét megjelentető DVD-vel.)

[5.] Gorove László [1820]: Szolnok várának viszontagságai. In.: Tudományos Gyüjtemény, 1820. IX. szám. $3-32$.

[6.] Gorove László [1820a]: A’ Szolnok vári viszontagságoknak folytatása. In.: Tudományos Gyüjtemény, 1820. X. szám. 35-57.

[7.] Gorove László [1820b]: A' Szolnok-vári viszontagságoknak folytatása. In.: Tudományos Gyüjtemény, 1820. XI. szám. 65-87.

[8.] Gorove László [1821]: A’ Szolnokvári viszontagságoknak folytatása. Szolnoknak mivólta az utólsó században. In.: Tudományos Gyüjtemény, 1821. VI. szám. 38-62.

[9.] Gorove László [1821a]: Szolnokvári viszontagságokhoz járuló toldalék. In.: Tudományos Gyüjtemény 1821. VIII. szám. 45-82.

[10.] Gyáni Gábor [2010]: Az elveszíthető múlt. Nyitott Könyvmúhely

[11.] Hild Viktor [1894]: Szolnok várának építése 1550-ben. In.: Jászság, 1894. júl. 22.

[12.] Hild Viktor [1925]: Szolnok várának építése. Szolnok és Vidéke, 1925. dec. 13

[13.] Illéssy János [1893]: Adatok a szolnoki vár felépítéséhez és első ostromához. Hadtörténelmi Közlemények 6, 635-666.

[14.] Kaposvári Gyula [1983]: A szolnoki vár kialakulása és helye a város települési képében. I. Szolnok térképes, rajzos ábrázolásai és topográfiai képe. 1685-től 1810-ig. In.: Szolnok Megyei Múzeumok Évkönyve, 1982/83. Szolnok, 161-204.

[15.] Kaposvári Gyula [1990]: A szolnoki vár kialakulása és helye a város települési képében. I. Szolnok város térképes és rajzos ábrázolásai. 1810-1910. In.: A Szolnok Megyei Múzeumok Évkönyve, VII. Szolnok, 231-305.

[16.] Kaposvári Gyula - Csányi Marietta [1974]: Szolnok-Vár, Gutenberg tér 4. In.: Régészeti Füzetek, 27. Budapest, 104-105.

[17.] [17.] Kertész Róbert [2012]: Fejezetek a török kori Szolnok kutatástörténetéhez és egy újabb azonosított objektum: a vesztőhely. In.: Szolnoki Tudományos Közlemények, XVI. 40-64. http://www.szolnok. mtesz.hu/sztk/index.html

[18.] Kertész Róbert - Sudár Balázs - Bana Zsolt - Kómár Mihály [2012]: Egy elfelejtett muszlim imahely: a szolnoki Szulejmán szultán-dzsámi. In.: Mǔemlékvédelem, 2012. 3. sz. 110-125.

[19.] Kósa Károly [2000]: Szolnoki mesék. In.: Szolnok. A várispánságtól a harmadik évezred küszöbéig. Szerk.: V. Szász József. Dinasztia Kiadó, 135-160.

[20.] Somogyi Ignác [1885]: Szolnok elfoglalása a török által. In.: Jász-Nagykun-Szolnok, IX. évf. 1885. márc. 22. [12. sz.] 1-2.

[21.] Somogyi Ignác [1886]: A szolnoki vár újjáépítésének története, 1550. I-VIII. In.: Jász-NagykunSzolnok, X. évf. 1886. jún. 6. [23. sz.] 1-2., jún. 13. [24. sz.] 1-2., jún. 20. [25. sz.] 1., jún. 27. [26. sz.] 1-2., júl. 4. [27. sz.] 1., júl. 18. [29. sz.] 1-2., aug. 15. [33. sz.] 1., aug. 22. [34. sz.] 2.

[22.] Somogyi Ignác [1887]: Hányszor jutott Szolnok város végső pusztulásra? 1-2. In.: Jász-NagykunSzolnok, 1887. jún. 19. [25. sz.] 2-3. p., jún. 26. [26. sz.] 2-3.

[23.] Somogyi Ignác [é.n.]: Szolnok város és a szolnoki tanács története 1740-1880-ig. Kézirat a szolnoki Damjanich János Múzeum könyvtárában.

[24.] Szendrei János [1889]: Szolnok eleste 1552-ben. Hadtörténelmi Közlemények, 125-140.

[25.] Vékony Gábor [2003]: A régészeti terepkutatás története Magyarországon. In.: A magyar régészet az ezredfordulón. Főszerk.: Visy Zsolt. Nemzeti Kulturális Örökség Minisztériuma, 15-21. 